\title{
THE INFLUENCE OF SCANNING SPEED ON THE LASER METAL DEPOSITION OF Ti/TiC POWDERS
}

\author{
VPLIV HITROSTI SKENIRANJA NA LASERSKO DEPOZICIJO \\ Ti/TiC PRAHU NA KOVINO
}

\author{
Kehinde Sobiyi, Esther Akinlabi, Stephen Akinlabi \\ University of Johannesburg, Department of Mechanical Engineering Science, Auckland Park Campus, 2006 Johannesburg, South Africa \\ kk_sob@yahoo.com
}

Prejem rokopisa - received: 2016-04-07; sprejem za objavo - accepted for publication: 2016-05-10

doi:10.17222/mit.2016.062

\begin{abstract}
The paper describes experimental work performed on the laser metal deposition (LMD) of titanium carbide powders on a pure titanium substrate. The understanding the effect of LMD processing parameters is vital in controlling the properties of the final product fabricated from the LMD process. The objective of the study is to characterize the influence of the laser scanning speed of the metal deposition of titanium and titanium carbide powders on a pure titanium substrate. Microstructural results showed that the substrate is characterized by two-phase morphology; alpha and beta phases. The deposit zone microstructures showed that the grains are of continuous columnar in nature. The heat-affected zone region grain areas appear to decrease with increasing in scanning speed for different samples at different scanning speeds. The height of samples was observed to decrease with an increase in the scanning speed. The microhardness results showed that the hardness of the deposits is greater than the hardness of the substrate. Wear-resistance performance results showed that the coefficient of friction of the substrate is greater than the coefficient of friction of the deposit samples. Similarly, the wear volume loss of material of the substrate is higher than the deposits. The deposit contains titanium carbide and, as such, this powder has improved the wear resistance performance of the substrate.
\end{abstract}

Keywords: titanium, lasers, metal deposition, scanning speed

Članek opisuje eksperimentalno delo pri laserskem nanašanju (angl. LMD) prahu titanovega karbida na podlago iz čistega titana. Upoštevanje učinkov LMD procesnih parametrov je ključno za kontrolo lastnosti končnega proizvoda, izdelanega z LMD postopkom. Namen študije je določiti vpliv hitrosti skeniranja laserja na nanašanje prahu kovinskega titana in titanovega karbida na podlago iz čistega titana. Rezultati mikrostrukturne karakterizacije so pokazali, da je za podlago značilna dvofazna morfologija; alfa- in beta faza. Mikrostruktura nanešene plasti je pokazala, da so zrna običajno stebraste strukture. Zrna v področju toplotno vplivane cone se zmanjšujejo z naraščanjem hitrosti skeniranja, pri različnih vzorcih in različnih hitrostih skeniranja. Višina vzorcev pri različnih hitrostih skeniranja, se je zmanjševala z naraščanjem hitrosti skeniranja. Rezultati mikrotrdote so pokazali, da je trdota nanosa večja od trdote podlage. Obnašanje pri obrabi je pokazalo, da je koeficient trenja podlage večji kot pa koeficient trenja nanosa. Izguba materiala zaradi obrabe je večja pri podlagi kot pa pri nanosu. Nanos vsebuje titanov karbid, zato je ta prah povečal obrabno odpornost podlage.

Ključne besede: titan, laserji, nanašanje kovine, hitrost skeniranja

\section{INTRODUCTION}

Titanium and its alloys are becoming widely used engineering materials, most especially in the aerospace, biomedical and chemical industries, due to its impressive mechanical properties such as, high-strength-to-weight ratio, high-temperature strength and excellent corrosion resistance. ${ }^{1,2}$ However, the use of titanium in severe wear applications is limited due to its poor tribological properties. ${ }^{3,4}$ Titanium alloys are very expensive to replace when damaged during their service life as a result of their high cost.

The Laser Metal Deposition (LMD) technique is efficient, cost effective, and environmentally friendly used for repairing or modifying components that were worn during service by improving its surface properties. ${ }^{3}$ The technique can be used for modifying the surfaces of titanium alloys using powder metals such as, ceramics, metals and alloys, composites and intermetallics, for improving its wear resistance, medical biocompatibility, corrosion and oxidation resistance. ${ }^{5}$

Several processing parameters such as laser power, scanning speed, powder rate, or gas flow rate are important during LMD. ${ }^{6,7}$ However, the efficiency of the LMD process is affected by the processing parameters which, in turn, affect the physical, microstructural, and microhardness profiling properties. Understanding the effects of these processing parameters during the LMD process, assist on controlling the resulting material properties. Although several studies have been performed to understand the effect of laser process parameters on the LMD process, only few attempts have been made to improve the wear properties of commercially pure titanium.

This study presents the effect of scanning speed on the microstructure and the wear of the resulting deposit using the LMD technique. 
K. K. SOBIYI et al.: THE INFLUENCE OF SCANNING SPEED ON THE LASER METAL DEPOSITION ...

\section{EXPERIMENTAL PART}

LMD of titanium (average particle size of $60 \mu \mathrm{m}$ ) and titanium carbide (average particle size of $200 \mu \mathrm{m}$ ) powders on the surface of $99.6 \%$ pure titanium substrate $(75 \mathrm{~mm} \times 75 \mathrm{~mm})$ was achieved using a Kuka robot, 4.4 KW Nd-YAG laser deposition machine. The experimental setup consisted of the following subsystems operating in a control system: the laser beam attached to the robot arm, dual powder feeding system hoppers (for the titanium and titanium carbide powders), and the control unit. The deposition was performed using a laser focal length of $195 \mathrm{~mm}$ and a beam diameter of $2 \mathrm{~mm}$. Figure 1 is a schematic diagram of the Kuka robot system used in the LMD process.

At the beginning of the experiment, a pre-test inspection is performed to eliminate factors that might affect the results. The substrate was sand blasted and then rinsed in acetone to clean the surface before the deposition process. After sand blasting, the powders were deposited on the surface of the substrate.

Six samples were prepared, each at a different laser scanning speed. The scanning speeds were varied from $0.3 \mathrm{~m} / \mathrm{min}$ and increased with an increment of $0.2 \mathrm{~m} / \mathrm{min}$ until $1.3 \mathrm{~m} / \mathrm{min}$. The experimental matrix is presented in Table 1. The laser power and powder volume flow rate for the powders were kept constant at $1200 \mathrm{~W}$ and $0.3 \mathrm{~min}^{-1}$, respectively.

The cladding powders were shielded by argon gas at a flow rate of $2 \mathrm{~L} / \mathrm{min}$ while depositing on the surface of the substrate. The oxygen level was kept in the $10 \mathrm{~min}^{-1}$ level using a glove box. The deposition process was achieved by feeding the powders onto the melting pool on the surface of the substrate.

Table 1: Experimental matrix

Tabela 1: Matrika preizkusov

\begin{tabular}{|c|c|c|c|}
\hline Samples & $\begin{array}{c}\text { Scanning speed } \\
(\mathrm{m} / \mathrm{min})\end{array}$ & $\begin{array}{c}\text { Ti powder flow } \\
\text { rate }\left(\mathrm{min}^{-1}\right)\end{array}$ & $\begin{array}{c}\text { TiC powder } \\
\text { flow rate }\left(\mathrm{min}^{-1}\right)\end{array}$ \\
\hline A & 0.3 & 1.7 & 0.3 \\
\hline B & 0.5 & 1.7 & 0.3 \\
\hline C & 0.7 & 1.7 & 0.3 \\
\hline D & 0.9 & 1.7 & 0.3 \\
\hline E & 1.1 & 1.7 & 0.3 \\
\hline F & 1.3 & 1.7 & 0.3 \\
\hline
\end{tabular}

Microscopic examination was performed on the laser deposit, to examine the defects that might affect the properties of the materials. Characterization was performed in accordance with the ASTM E3-11 standards for preparing the samples.

Small pieces of samples for each scanning speed were cut from the substrate, cleaned, mounted using polyfast resin. The substrate was grinded to achieve a smooth surface, using silicon carbide paper (320 grit), MD-largo and DiaPro. Polishing was done using MD-Chem cloth with OP-S mixture as the suspension. Each sample was etched for $25 \mathrm{~s}$ using Nital solution.

The microstructure and the surface topography of the substrate were observed using an optical microscope (Olympus BX51M). Microhardness was performed using a Vickers testing machine $\left(\right.$ EMCOTEST $\left.^{\circledR}\right)$, and a test load of $500 \mathrm{~g} / \mathrm{f}$ was used. Ten indentations were applied per sample and the average diagonal values of the samples were recorded. The micrograph of the wear scars was observed under the TESCAN scanning electron

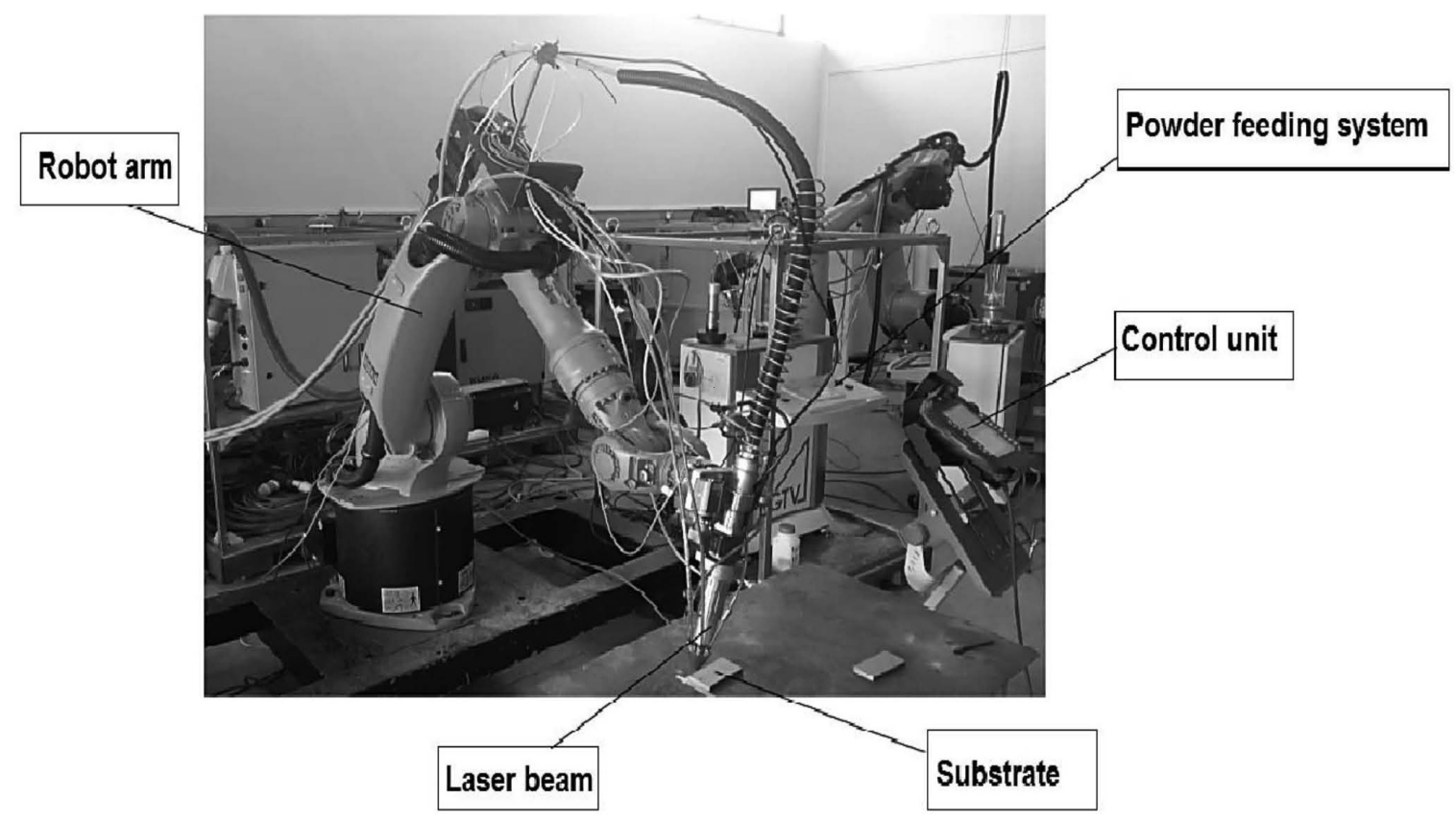

Figure 1: Kuka robot system used for laser deposition process

Slika 1: Kuka robotski sistem, uporabljen pri postopku nanašanja z laserjem 
K. K. SOBIYI et al.: THE INFLUENCE OF SCANNING SPEED ON THE LASER METAL DEPOSITION ...

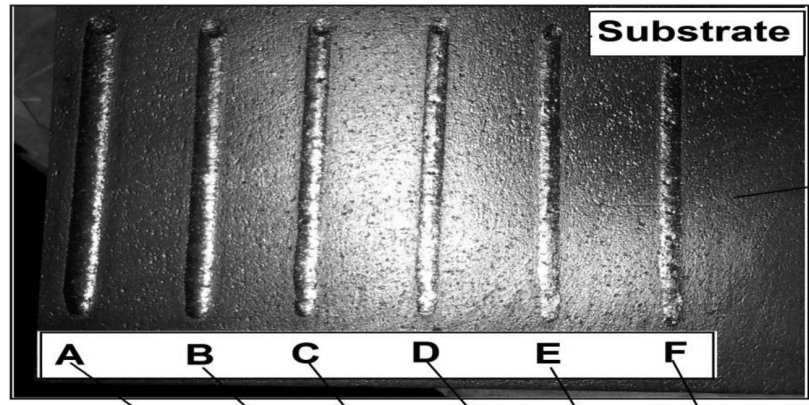

Deposit

Figure 2: Physical appearance of the deposits Slika 2: Fizični izgled nanosov

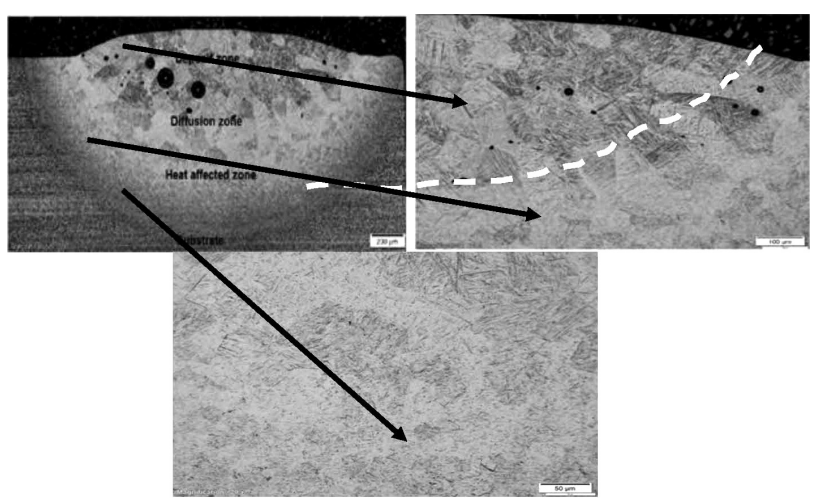

Figure 3: a) Morphology of sample A, b) enlarged deposit zone and diffusion zone, c) enlarged heat-affected zone

Slika 3: a) Morfologija vzorca A, b) povečano področje nanašanja in področje difuzije ter c) povečano toplotno vplivano področje

microscope (SESCAN) equipped with an Oxford Instruments energy-dispersive X-ray spectrometer (EDS).
A dry sliding wear test was performed on the deposited surfaces to investigate the wear resistance of the substrate at different laser scanning speeds, according to ASTM G133-05 standard using a pin-on-disk tribometer (by Cert). The sample was preloaded with a tungsten carbide ball of diameter $10 \mathrm{~mm}$ at $25 \mathrm{~N}$ force for the 10 $\mathrm{s}$, and then loaded with the same force $25 \mathrm{~N}$ for $1000 \mathrm{~m}$. The coefficient of friction, lateral force, horizontal force and carriage position were plotted against time for 1000 seconds. The wear volume loss of material on the substrate is calculated from Equation 1:

$V_{\text {total }}=V_{A}+V_{B}=L\left\{r^{2} \sin ^{-1}\left(\frac{W}{2 r}\right)-\frac{W}{2}\left(r^{2}-\frac{W^{2}}{4}\right)^{1 / 2}\right\}+$

$+\frac{\pi}{3}\left\{2 r^{3}-2 r^{2}\left(r^{2}-\frac{W^{2}}{4}\right)^{1 / 2}-\frac{W^{2}}{4}\left(r^{2}-\frac{W^{2}}{4}\right)^{1 / 2}\right\}$

\section{RESULTS AND DISCUSSION}

\subsection{Effect of speed on laser metal deposition}

Figure 2 shows the physical appearance of the deposits on the substrate after LMD of the titanium carbide powders. The thicknesses of the layers varies with scanning speeds. At a low scanning speed the thickness appears to be bigger and wider than the thickness at a high scanning speed. Observed the texture of the surface at lower scanning speed appears more rough compared to the surface texture at higher scanning speeds. This is probably due to more powders were melted on the surface of the substrate, thus enhancing the surface texture. The microstructure of the laser deposit was observed to be relatively homogeneous. The deposits were generally free from cracks but pores were

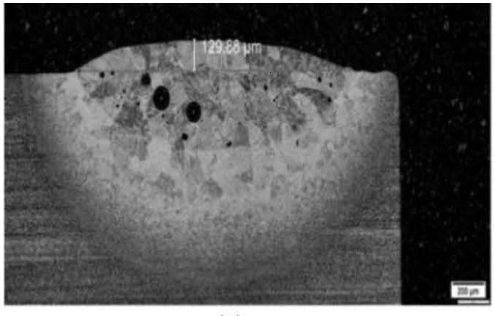

(a)

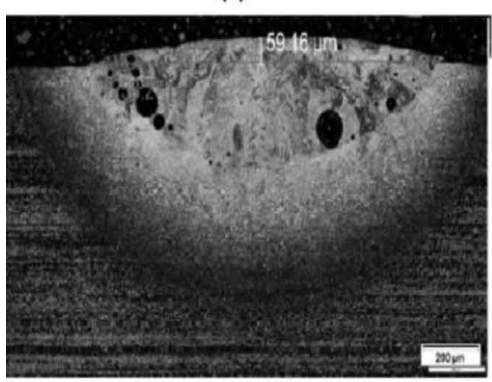

(d)

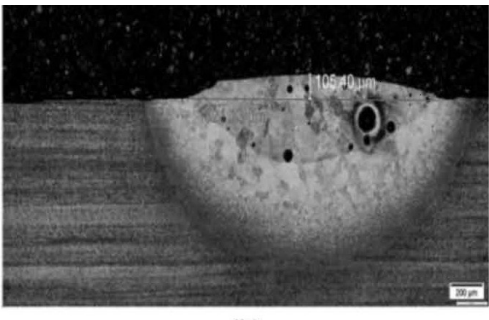

(b)

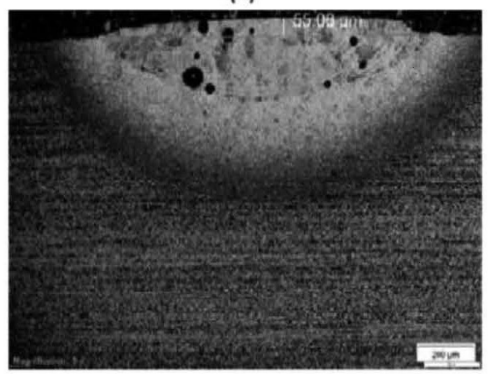

(e)

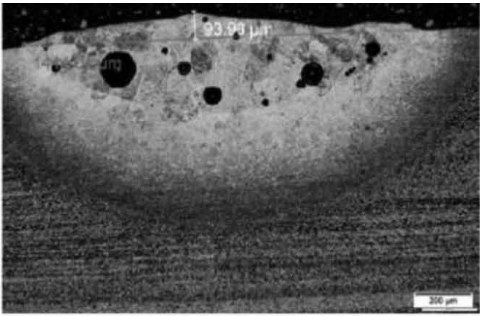

(c)

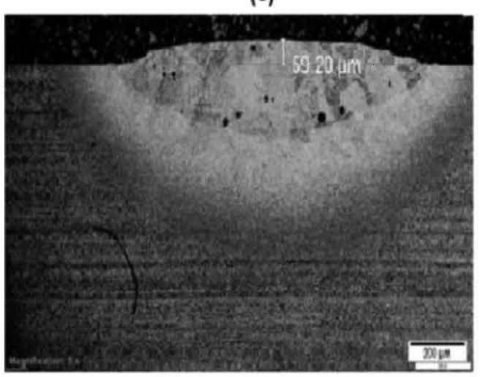

(f)

Figure 4: Morphology of the samples with deposit height

Slika 4: Morfologija vzorcev $\mathrm{z}$ višino nanosa 
observed (Figure 4), caused by gas produced from the in situ, entrapped within the molten pool during the deposition process..$^{4,8}$

Figure 3a shows the morphology of sample A and Figure $3 \mathbf{b}$ the enlarged view of the deposit zone and diffusion zone, at scanning speed of $0.3 \mathrm{~m} / \mathrm{min}$. The deposit zone, diffusion zone and heat-affected zone (HAZ) were observed in Figure 3. The deposit zone is the layer of powder deposited on the substrate. The diffusion zone is the mixture of the deposition powder and the substrate material resulting after the laser metal deposition process. The HAZ is the portion on the surface of the substrate altered by heat during the deposition process. The deposit zone and diffusion zone appear to have a similar grains structure characterized by the grains of the beta phase. The deposit zone and the diffusion zone are all characterized by the grains of the beta phase. From the microstructure, it can be noticed that the deposit zone grains are of a continuous columnar nature, confirming the beta phase. As the laser scanning speed increases the alpha phase is noticed to be developing.

With the other samples, the deposit zone region is noticed to be decreasing with an increase in the scanning speed. This is a result of heat received by the region during deposition, which cause microstructural changes in that region. As the scanning speed increases the time it takes for the laser to complete the deposit decreases. It can also be observed that as the scanning speed increases the grains appear to be decreasing and more regions of alpha phase are appearing on the microstructures of the samples.

The grains on the heat-affected region appear to be characterized by beta phase, similar to that observed by R. M. Mahamood et al. ${ }^{9}$ Generally, at a low laser scanning speed, there is a good bonding between the substrate material and the deposit powder. ${ }^{9}$ The material of sample A is fully dense compared to material of the sample scanned at a high laser scanning speed. The optical micrograph of the other five samples is shown in Figures

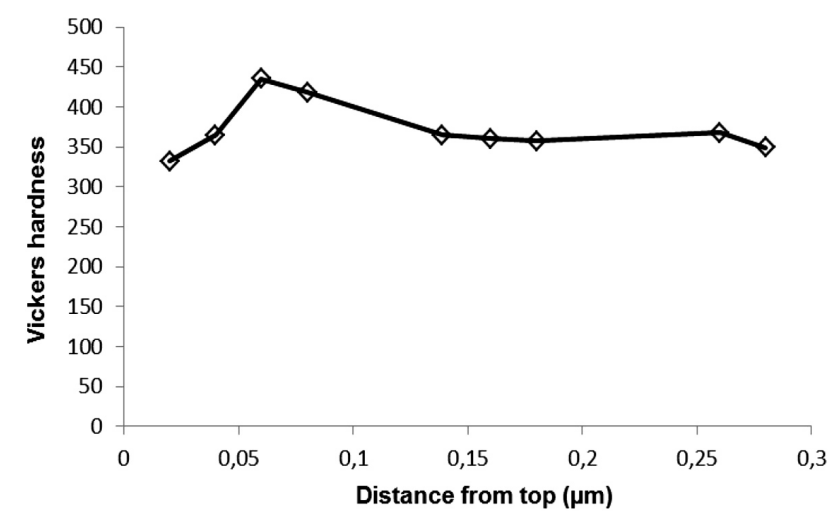

Figure 5: Microhardness profile of sample A at a scanning speed of $0.3 \mathrm{~m} / \mathrm{min}$

Slika 5: Profil mikrotrdote vzorca A pri hitrosti skeniranja $0,3 \mathrm{~m} / \mathrm{min}$

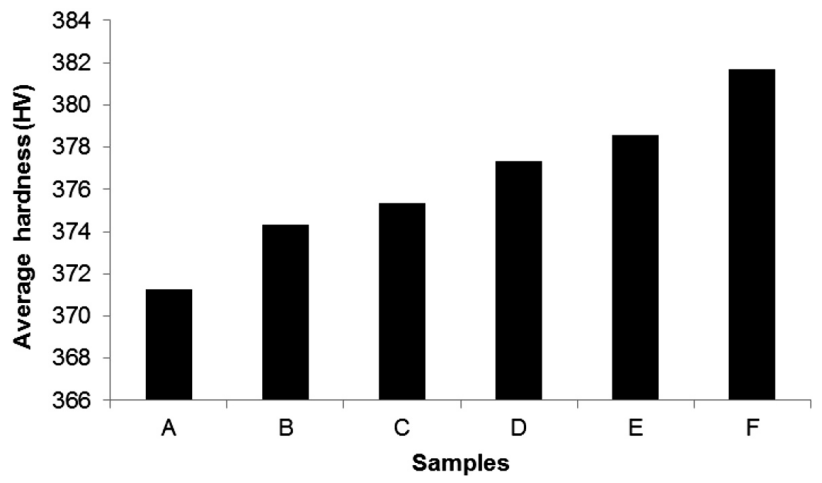

Figure 6: Graphical representation of average hardness for all the samples

Slika 6: Grafična predstavitev povprečne trdote za vse vzorce

4b to 4f). Comparing Sample A and sample F in Figure $\mathbf{4 f}$, it can be noticed that areas of HAZ are different. For sample $\mathrm{F}$ the area is very small and for sample A the area is large.

The area of the HAZ appears to decrease as the scanning speed increases. The HAZ region of sample B is characterized by a microstructure with grains less that the grains of sample A. As the scanning speed increases the melt pool gets bigger and the solidification becomes slower, causing the materials of the substrate to melt deeper, causing the substrate to mix more of its material with the deposit material, thus, the deposit height decreases. ${ }^{10}$

The HAZ area of sample F where the scanning speed is $1.3 \mathrm{~m} / \mathrm{min}$ is characterized with fewer refined grains formed in that area compared to the HAZ of sample A where the scanning speed is $0.3 \mathrm{~m} / \mathrm{min}$. This is caused by heat received by the area, which cause microstructural changes in that area.

The deposit zone of sample A was measured to be $129.88 \mu \mathrm{m}$. The heights of the other samples (B-F) were $105.4 \mu \mathrm{m}, 93.96 \mu \mathrm{m}, 59.16 \mu \mathrm{m}, 55.08 \mu \mathrm{m}$ and $59.20 \mu \mathrm{m}$ respectively. Comparing measured heights of all samples and height of sample $\mathrm{A}$ it can be seen that the height decreases with increase in scanning speed.

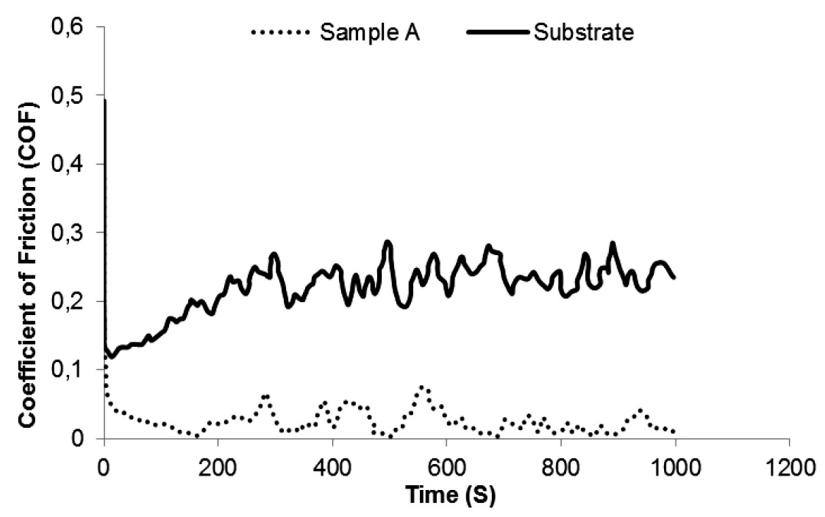

Figure 7: Graphical representation of coefficient of friction (COF) with time

Slika 7: Grafična predstavitev koeficienta trenja v odvisnosti od časa 
K. K. SOBIYI et al.: THE INFLUENCE OF SCANNING SPEED ON THE LASER METAL DEPOSITION ...

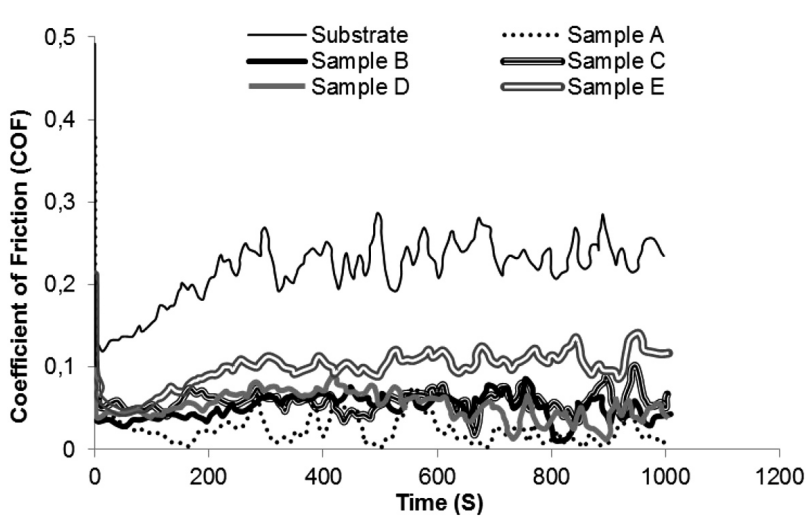

Figure 8: Graphical representation of average coefficient of friction Slika 8: Grafična predstavitev povprečja koeficienta trenja v odvisnosti od časa

Figure 5 shows a graphical representation of the microhardness profile measured across the section of the sample A from top to bottom. The first three hardness measurements were taken on the deposit zone region, the next three measurements were taken on the HAZ region and the last three measurements were taken on the substrate material region. From the graphical representation of the microhardness profile results, it can be observed that the hardness increases initially and then later decreases towards the substrate. The higher hardness experienced at the transition between the deposit and HAZ zone can be attributed to possibly better crystallization of the grains in this zone. Similar was observed with the other five samples. This shows that the addition of titanium carbide powder improves the mechanical properties of the substrate, and the heat generated by the laser affects the mechanical properties of the substrate.

Figure 6 shows the experimental average microhardness for all six samples. From the graphical representation of the results it can be noticed that the average hardness increased with an increase in the scanning speed. At a higher scanning speed there is rapid solidification of the deposit, which reduces the time taken for the melt pool to solidify, thus promoting higher hardness.

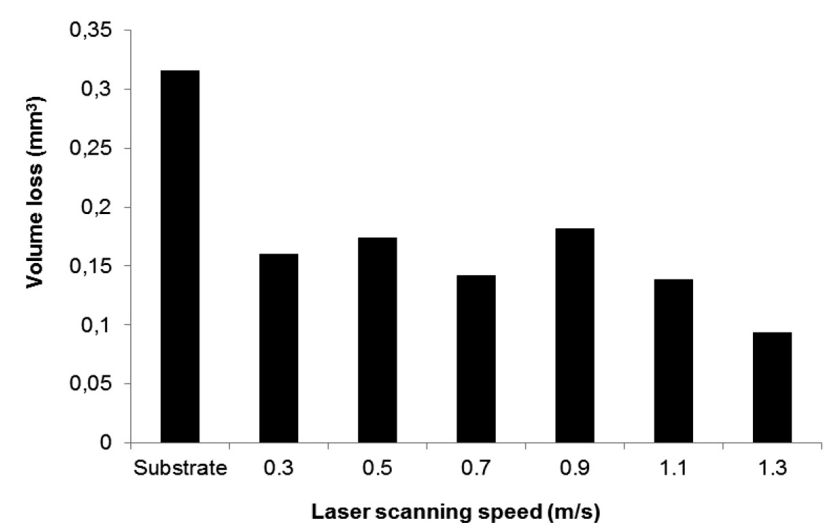

Figure 9: Graphical representation of wear volume loss Slika 9: Grafična predstavitev volumske izgube pri obrabi
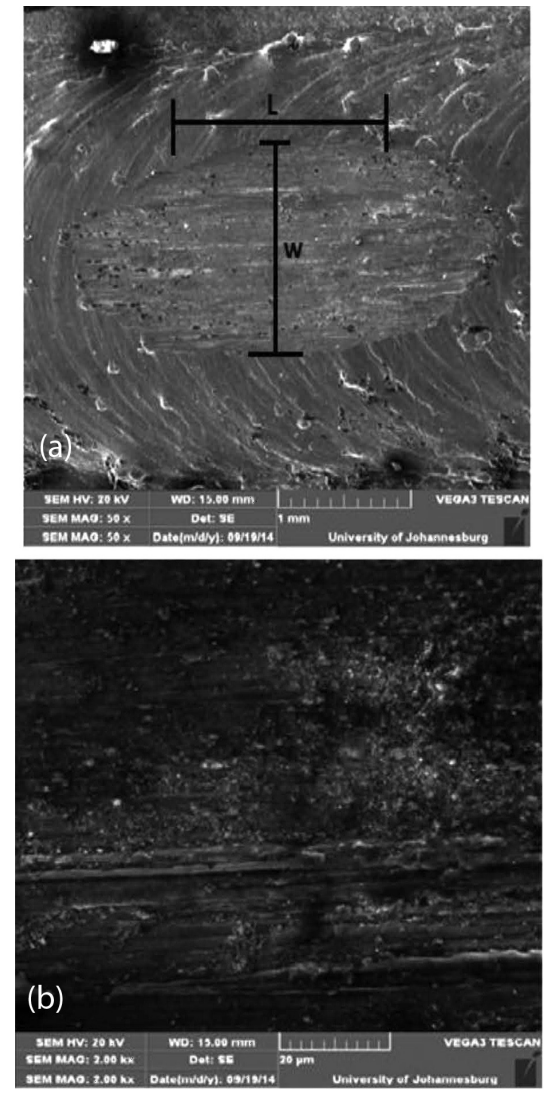

Figure 10: SEM morphology of sample A wear scar: a) low magnification, b) high magnification

Slika 10: SEM-morfologija področja obrabe vzorca A: a) pri majhni povečavi, b) pri večji povečavi

\subsection{Wear resistance behaviour}

In Figure 7, the experimental coefficient of friction for sample A and the substrate are shown for the dry sliding wear resistance tests. From the graphical representation of the results it can be noticed that the coefficient of friction of the substrate is higher than the coefficient of friction. Similar result was obtained for all the other samples investigated.

The titanium wear resistance is found to be very poor compared to the deposit layer as a result of its high coefficient of friction and higher chemical affinity with the tungsten carbide ball used for the wear test thus it is expected for the substrate material to have a high wear volume loss of material. ${ }^{10,11}$ The coefficient of friction of the deposits of all other samples is lower than the one of the substrate resulting from the melted TiC particles on the surface. Titanium carbide powder was used as a reinforcement in this study.

In Figure 8, the average coefficient of friction at increasing scanning speed corresponding to the individual samples is shown for the dry sliding wear performance testing. The graphical representation of the results shows that the coefficient of friction increases with an increase in the scanning speed; as a result, sample A has a smaller 
K. K. SOBIYI et al.: THE INFLUENCE OF SCANNING SPEED ON THE LASER METAL DEPOSITION ...

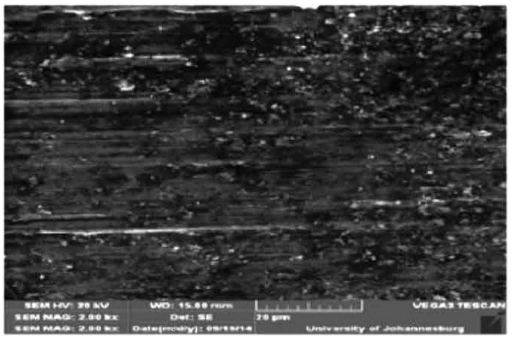

(a)

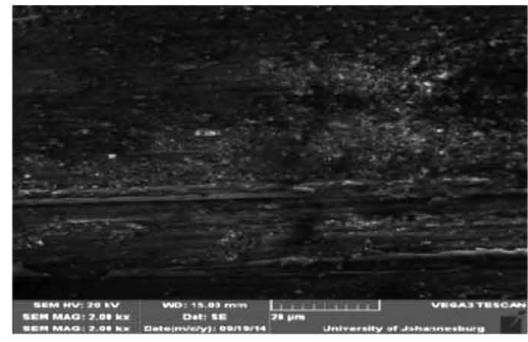

(d)

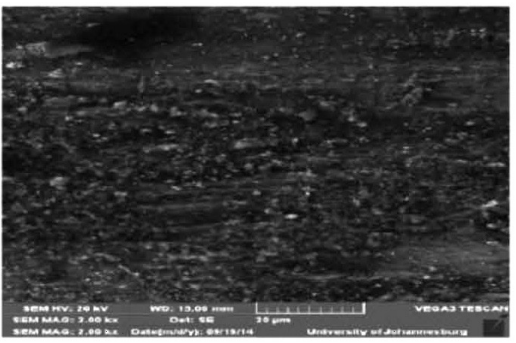

(b)

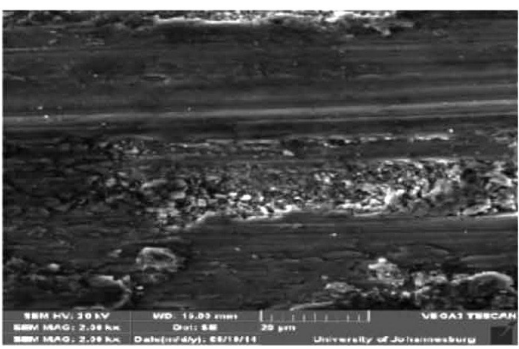

(e)

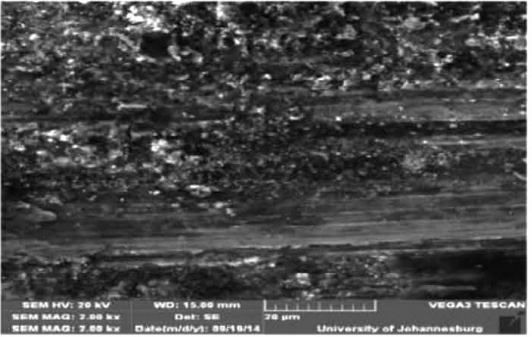

(c)

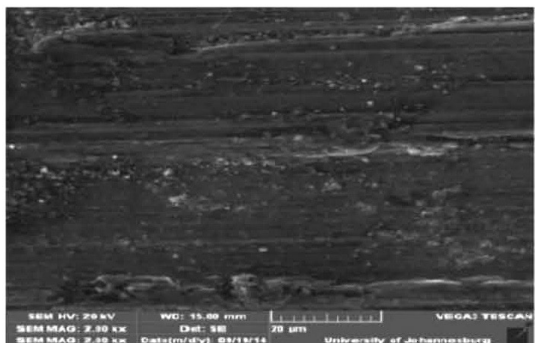

(f)

Figure 11: SEM images of wear tracks at 2000x: a) sample A at $0.3 \mathrm{~m} / \mathrm{min}$, b) sample $\mathrm{B}$ at $0.5 \mathrm{~m} / \mathrm{min}, \mathrm{c}$ ) sample C at $0.7 \mathrm{~m} / \mathrm{min}$, d) sample D at $0.9 \mathrm{~m} / \mathrm{min}$, e) sample $E$ at $1.1 \mathrm{~m} / \mathrm{min}, \mathrm{f}$ ) sample $\mathrm{F}$ at $1.3 \mathrm{~m} / \mathrm{min}$

Slika 11: SEM-posnetki sledov obrabe pri $2000 \times$ povečavi: a) vzorec A pri $0,3 \mathrm{~m} / \mathrm{min}$, b) vzorec B pri $0,5 \mathrm{~m} / \mathrm{min}$, c) vzorec C pri $0,7 \mathrm{~m} / \mathrm{min}$, d) vzorec D pri $0,9 \mathrm{~m} / \mathrm{min}$, e) vzorec E pri $1,1 \mathrm{~m} / \mathrm{min}$ in $\mathrm{f}$ ) vzorec $\mathrm{F}$ pri $1,3 \mathrm{~m} / \mathrm{min}$

coefficient compared to sample F. Consequently, the substrate is observed to have the highest coefficient of friction.

Figure 9 shows the experimental wear volume loss at different scanning speeds. The figure shows a higher volume of material removal from the surface of the substrate compared to the volume loss of material of the samples at different scanning speeds. The titanium wear resistance is very poor, so it is expected that the substrate material will have a high wear volume loss of material. On the deposit the wear volume loss will be at a minimum level as the deposit layers contain titanium carbide powder melted on the surface of the substrate. The presence of titanium carbide reinforced composite layer improved the wear resistance of the substrate.

Figure 10 shows the SEM micrograph of sample A at low and high magnifications. From the figure, a large scar was observed, with the appearance of large width and long length, which is an indication of wear on the surface of the sample. Un-melted particles of titanium carbide powder were also observed on the surface of the substrate, as shown in Figure 10a.

The morphology of wear scars for all other five samples are at higher magnification is shown in Figure $\mathbf{1 1 .}$ Surface defects such as pits and wear debris were observed along the wear tracks; an indicating abrasive and adhesive wear mechanism which is coupled with severe plastic deformation around the edges of the wear scars.

\section{CONCLUSION}

The study investigated the characterization of the influence of the laser scanning speed of LMD for titanium and titanium carbide powders on a titanium alloy substrate.

The results obtained through the characterization of the influence of the laser scanning speed of the laser deposition for titanium and titanium carbide powders has shown that the laser process parameters have an effect on the material properties of components subjected to the LMD process. The microstructure of each sample of different laser deposition scanning speeds showed that the HAZ region increased with an increase in the scanning speed and the heights of the deposits were observed to be different for different laser scanning speeds of the powder particles.

The microhardness results showed that different zones on the substrate have different hardness properties. The hardness decreases from the deposit zone, HAZ and from the HAZ to the substrate. The microhardness was found to increase with an increase in the scanning speed for all the samples investigated. This was a result of the time taken by the laser to interact with the substrate material. These results showed that at a lower scanning speed the laser interacts with the material for a long period of time, which takes longer to solidify the deposits, which in turn affects the results of hardness. This shows that at a lower laser scanning speed the degree of mixing for the substrate material with the deposited powder is proper.

The results of the wear resistance performance behavior of the samples at different scanning speeds and 
the substrate indicates that the wear volume of material removed from the surface of the substrate is higher than the wear volume of the material removed from the deposit surface. The coefficient of friction of the substrate was observed to be higher than the coefficient of friction of the samples at different scanning speeds. The deposition of titanium carbide showed that the volume loss of material from the substrate could be reduced. Titanium carbide improved the wear resistance of the component. The SEM analysis showed that at a low laser scanning speed some powder particles are completely melted on the surface of the substrate.

\section{Acknowledgments}

The authors would like to thank NLC Council for Science and Industrial Research for the use of their Nd: YAG laser deposition machine and Tshwane University of Technology for their wear resistance testing apparatus.

\section{REFERENCES}

${ }^{1}$ F. H. Froes, The titanium image: Facing the realities of life, The Journal of The Minerals, Metals \& Materials Society (JOM), 52 (2000) 5, 12, doi:10.1007/s11837-000-0023-2

${ }^{2}$ K. K. Sobiyi, D. C. Blaine, Initial Studies in Powder Metallurgy processing of titanium, Proceedings of The Southern African Institute of Mining and Metallurgy, Advanced Metals Initiative (AMI), 2010, 105-119
${ }^{3}$ B. Graf, A. Gumenyuk, M. Rethmeier, Laser metal deposition as repair technology for stainless steel and titanium alloys, Physics Procedia, 39 (2012), 376-38, doi:10.1016/j.phpro.2012.10.051

${ }^{4}$ Y. S. Tian, C. Z. Chen, S. T. Li, Q. H. Huo, Research progress on laser surface modification of titanium alloys, Applied Surface Science, 242 (2005) 1-2, 177-184, doi:10.1016/j.apsusc.2004.08.011

${ }^{5}$ F. Weng, C. Chen, H. Yu, Research status of laser cladding on titanium and its alloys: A review, Materials and Design, 58 (2014), 412-425, doi:10.1016/j.matdes.2014.01.077

${ }^{6}$ R. M. Mahamood, E. T. Akinlabi, M. Shukla, S. Pityana, Effect of scanning speed on material efficiency of laser metal deposition of Ti6Al4V, Proceedings of World Academy of Science, Engineering and Technology, 71 (2012), 1531-1535

${ }^{7}$ Y. Sun, M. Hao, Statistical analysis and optimization of the process parameters in Ti6A14V laser cladding using Nd:YAG laser, Optics and lasers in Engineering, 50 (2012) 7, 985-995, doi:10.1016/ j.optlaseng.2012.01.018

${ }^{8}$ J. Sampedro, I. Perez, B. Carcel, J.A. Ramos, V. Amigo, Laser cladding of TiC for better titanium components, Physics Procedia, 12 (2011), 313-322, doi:10.1016/j.phpro.2011.03.040

${ }^{9}$ R. M. Mahamood, E. T. Akinlabi, M. Shukla, S. Pityana, Scanning velocity influence on microstructure, microhardness and wear resistance performance on laser deposited Ti6Al4V/TiC composite, Materials and Design., 50 (2013), 656-666, doi:10.1016/j.matdes. 2013.03.049

${ }^{10}$ R. M. Mahamood, E.T. Akinlabi, M. Shukla, S. Pityana, Laser Metal Deposition of Ti6Al4V: study on the effect of laser power on microstructure and Microhardness, Proceedings of the International Multi Conference of Engineers and Computer Scientist, Vol. II, 2013

${ }^{11}$ C. Guo, J. Zhou, J. Chen, J. Zhao, Y. Yu, H. Zhou, Improvement of the oxidation and wear resistance of pure $\mathrm{Ti}$ by laser cladding at elevated temperature, Surface Coating Technology, 205, (2010) 7 , 2142-2151, doi:10.1016/j.surfcoat.2010.08.125 